\title{
"Pırıl" Çizgi Filminin Değerler Eğitimi Açısından Değerlendirilmesi
}

\author{
DOI: $10.26466 /$ opus.752885
}

\author{
Zehra Güden Altmiș* - Mustafa Altun ** \\ * Doktora Öğrencisi, Sakarya Üniversitesi Sakarya/Türkiye \\ E-Posta: zehrabade@gmail.com \\ ORCID: $\quad$ 0000-0001-8866-0158 \\ ** Doç. Dr., Sakarya Üniversitesi Sakarya/Türkiye \\ E-Posta: maltun@sakarya.edu.tr \\ ORCID: $\underline{0000-0002-1826-793 X}$
}

Öz

Günümüzde hırsızlık, cinayet, tecavüz gibi suçlar oldukça yaygınlaşmıştır. Bu durum değerler eğitiminin önem kazanmasına neden olmuştur. Çizgi filmler özellikle çocukların hayatında önemli bir yere sahiptir. Bu nedenle çocuklarm izledikleri çizgi filmlerin özelliklerinin iyi bilinmesi gerekir. Bu araştırmada TRT Çocuk kanalında yayınlanan yerli bir yapım olan Pırıl çizgi filmi değerler eğitimi açısından incelenmiştir. Araştırmada nitel araştırma yöntemlerinden olan doküman incelemesi tekniğgi kullanılmıştır. Çizgi filmin Youtube üzerinden en çok izlenen 5 bölümü içerik analizi yoluyla en az iki kez izlenerek taranmıştır. Birkök'ün değerler sınıflandırması ile Maslow'un İhtiyaçlar Hiyerarşisi'ni ilişkilendiren yaklaşımından hareketle bir değerler tablosu hazırlanmıştır. 5 bölümün tamamı içerik analiz türlerinden kategorisel içerik analizi yöntemi ile incelenmiştir. Araştırmada değerler ayrı ayr başlıklar halinde verilmiş ve çizgi filmin bölümlerinden örneklendirilmiştir. Araştırmanın sonunda çizgi filmde sorumluluk, öğ̈̈t verme, yardımseverlik, estetik, dostluk, nezaket, bilme ve anlama isteğ $i$, güven, özgüven, cömertlik, teselli etme, hoşgörü, dürüstlük, sevgi ve pişmanlık olmak üzere 15 değer tespit edilmiştir. Bunlar içerisinde en fazla yer alan değer "nezaket"tir. Ayruca "estetik ve sorumluluk" değerleri de çok geçen değerler arasında belirtilmiştir.

Anahtar Kelimeler: Değer, eğitim, değer eğitimi, çizgi film.

\footnotetext{
* Bu makale Doç. Dr. Mustafa Altun danışmanlığındaki "9-11 Yaş Grubu Çocuklara Yönelik Türk Yapımı Çizgi Filmlerde Değerler Eğitimi" adlı doktora tezinden türetilmiştir..
} 
ISSN:2528-9527

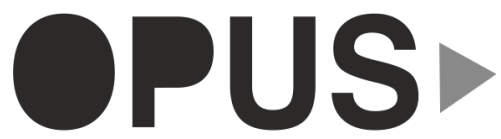

E-ISSN : 2528-9535

YIl Year: 11

Cilt Volume: 17

Sayı Issue :38

Uluslararası Toplum Araştırmaları Dergisi

Haziran June 2021

International Journal of Society Researches

Makalenin Gelis Tarihi Received Date: 15/06/2020

Makalenin Kabul Tarihi Accepted Date: 22/02/2021

\title{
Evaluation of "Pirıl" Cartoon in Terms of Values Education
}

*

\begin{abstract}
Crimes such as theft, murder and rape have become quite common today. This situation caused the values education to gain importance. Cartoons have an important place especially in children's life. For this reason the characteristics of the cartoons that children watch must be well known. In this research "Purll" cartoon which is the local production published on TRT Çocuk channel was examined in terms of values education. The document review technique, which is one of the qualitative research, methods was used in the research. The 5 most watched episodes of the cartoon were screened by watching them at least twicw through content anlysis. A table of values was prepared based on Birkök's classification of values and Maslow's approach to the Hierarchy of Nedds. All 5 sections were analyzed by categorical content analysis method, one of the content analysis types. In our research values are given in separate titles and exemplified from the parts of the cartoon. At the end of the research 15 values were determined in the cartoon responsibility, courtesy, benevolence, aesthetics, friendship, kindness desire to know and understand, trust, self-confidence, generosity, confort, tolerance, honesty, love and regret. The most included value among this is "courtesy". In addition the values of "aesthetics and responsibility" are among the very past values.
\end{abstract}

Keywords: Value, education, value education, cartoon. 


\section{Giriş}

Teknolojinin gelişmesiyle birlikte bireyler bebeklikten itibaren teknolojik cihazlarla etkileşim halinde olmaktadır. Günümüzde televizyon, bilgisayar, cep telefonu gibi cihazların kullanımı gündelik yaşamın bir parçası haline gelmiştir. Bu cihazlardan özellikle televizyonun çocuklar üzerinde olumlu ve olumsuz etkileri bulunmaktadır.

"Çocuklar daha okuma yazma öğrenmeden önce, belirli sürelerde televizyon izlemekte kendine göre televizyon programları seçmektedir." (Can,1996, s.101) Seçilen bu programların bir kısmı çocuğa yarar sağlarken bir kısmı zararlı ögeler içerebilmektedir.

Yetişkinler televizyon karşısında kısmen de olsa bilinçli ve istekli bir tavır geliştirebilmektedir. Çocukların televizyon karşısında daha edilgin bir konumda olmaları, televizyon ve çocuk ilişkisini daha dikkate değer kılmaktadır (Güneş, 2010, s.56).

Çocuk zihinsel süreçlerindeki özelliklerinden dolayı izlediklerini yetişkinler gibi algılayamamakta ve yetişkinlerden daha farklı şekilde izlediklerinden etkilenmektedirler. Birçok açıdan televizyon karşısında yetişkinlere oranla daha korunmasız durumda olan çocuklar, "hayal ile gerçek" arasındaki farkı yetişkinler kadar kolay biçimde görememektedirler (Öztürk ve Karayağız, 2007, s.84). Bu nedenle çocukların izledikleri programların ebeveynlerin kontrolü altında olması oldukça önem taşımaktadır. Gerçeğe uygun olmayan karakterlerle yüklü programları izleyen çocuklar bu karakterleri örnek alarak onların yaptıkları olağanüstü şeyleri yapmaya çalışmakta ve kendilerine zarar verebilmektedirler.

Televizyon ve çocuk ilişkisini ele alan çalışmalarda en çok üzerinde durulan konu: televizyonun çocuklar üzerinde olumsuz etkileri bulunduğu konusudur. Televizyon izlenimine ağırlık verildiğinden derslerin ihmal edildiğini, okuma becerisini geciktirdiğini ve çizgi filmlerdeki şiddet dolu sahnelerdeki saldırgan hareketlerin çocuk üzerinde olumsuz etkileri konusunda çeşitli araştırmalar yapılmıştır. Çocukların, okul öncesinde çok fazla televizyon izlemeleri onların okuldaki başarılarının ve sosyal ilişkilerini etkilemektedir. Bu konuda New Orleans'da yapılan bir araştırmada, okul öncesinde çok fazla televizyon izleyen birinci sınıf öğrencilerinin notlarının daha az 
televizyon izleyenlere göre daha düşük olduğu belirlenmiştir (Çilenti, 1980, s.58).

Televizyonun aile, okul ve öğretmenlerin önüne geçtiği düşüncesi son zamanlarda daha da kabul gören bir düşünce hâline geliyor olsa da eğitimde öğretimi zenginleştirmek için televizyondan yararlanılmalıdır (Okur ve Göçen, 2012, s.1991).

Özkan'ın üniversite öğrencileri arasında yaptığı çalışmasında paylaştığı gibi televizyon programları, toplumsal fayda gözetilerek yayın yapıldığında birçok eğitim kurumunun yaptığ yapabilecek durumdadır (Özkan, 2004, s.55). Son dönemlerde özellikle çocuklar için hazırlanan programlar, çizgi filmler göz önünde bulundurulduğunda bunların çoğunun eğlendirirken eğitme amacı güttüğü söylenebilir.

Çilenti televizyonun çocuk eğitiminde olumlu etkilerini şu şekilde siralar:

1. Çocukları eve bağlar, aile bireylerini bir araya toplayarak aralarında yeni ortak ilgilerin doğmasını sağlar, böylece de aile hayatını mutlu ve ilginç hâle getirir.

2. Aileler için bir kültür kaynağı ödevi görür.

3. Çocukları düşünmeye teşvik eder.

4. Çocukların, boş zamanlarını iyi değerlendirmelerini sağlayacak ilgiler uyandırır, onların ilgi ve yaşantı alanlarını genişletir.

5. Çocukların estetik zevklerini geliştirir (Çilenti, 1980, s.55).

Büyükbaykal'a göre televizyon izleyen çocuklarda öncelikli olarak ders çalışmaya karşı isteksizlik, okuma alışkanlığının yerleşmemesi, şiddete başvurma ve saldırganlığın artması, kendini doğru bir biçimde ifade edememe, kendini televizyondan izlediği kahramanın yerine koyarak gerçeklerden uzaklaşma, toplumsal ilişkilerde güçlüklerle karşılaşma ve uzun süre televizyon karşısında kalmanın yarattığı çeşitli sağlık sorunları televizyonun olumsuz etkilerinin birer sonucudur (Büyükbaykal, 2012).

Schmidt ve Vandewater da televizyonun çocuğa yönelik etkilerini içerik açısından değerlendiriyor, çocuğun televizyonda eğitici 
programlar izlemesinin akademik başarısı ile olumlu ilişkisi olduğunu; eğlence programlarını izlemesinin ise başarı ile olumsuz ilişkisi olduğunu vurguluyor (Schmidt ve Vandewater, 2008).

Çizgi filmler çocukların favori izleme tercihleridir. Çizgi filmler çok eğlencelidir ve çocuklar sıkılmaktan hoşlanmazlar. Çizgi filmler aynı zamanda çocukların çok şey öğretir ve çocukların hayal gücünü genişletir. Bunun yanında birçok çizgi film fantastiktir, bu durum çocukları gerçeklerden uzaklaştırır. Maalesef birçok çizgi film şiddet ve kötü dil içerir, çocukların zihinlerinde negative bir etki bırakırlar; çocukların zihinleri birer sünger gibidir duyduğu ve gördüğü her şeyi emer (Garden, 2008). Çocuklar televizyonda gördüklerini radyoda duyduklarından daha iyi hatırlarlar çünkü görsel ögeler hatırlamaya yardım eder (Wade \& Travis, 1993, s.65). Bu şekilde çizgi filmler kalıcı öğrenmenin gerçekleşmesine katkıda bulunur.

Çizgi filmlerin, toplumsal eğitim açısından faydalarına bakıldığında çok etkin bir rol üstlendiği görülmektedir. Değerler eğitimi de dâhil olmak üzere pek çok konu, bilgi, olay ve kavram çocuk programları içinde animasyon kullanılarak sunulmaktadır. Animasyonun yüklendiği bu görev, çocuğun eğitim süreci içerisindeki kişilik gelişimini istenildiği şekilde mesajlarla yönlendirebilmektedir (Kaba,1992, s.54).

Eğitim açısından yapılan çizgi filmlerde daha çok gerçek olgulara ve çocukların gelişimsel özelikleri dikkate alınarak, çocukların hayatlarında kullanacakları bazı davranışları kazanmalarına yardımcı konular ele alınır (Can, 1996, s.87). Özellikle sayıların, harflerin ve renklerin öğretimi, toplumsal değerler, sorumluluk, arkadaşlık ve dostluk gibi insan ilişkilerini konu alan çizgi filmler günümüzde daha çok değer kazanmaktadır (Özeskici, 2014, s.22). Bu durum çizgi filmlerin değer eğitimi açısından daha önemli hâle gelmesine neden olmuştur.

Maslow'a göre, sağlıklı bir benlik bir değerler sistemine ihtiyaç duymaktadır; yani bir yaşam felsefesine, bir dine ya da dinin yerini alan bir sisteme. Bu ihtiyacın da güneş ışıklarına, vitamine, sevgiye duyulan ihtiyaç kadar hayatî olduğunu söylemektedir, zira bu insanın anlamaya karşı duyduğu bilişsel ihtiyacın bir yansımasıdır (Çakmak, 2018, s.29). 
Maslow, değerlerin insanın yapısında bulunduğunu ifade etmektedir. Biyolojik ve kalıtsal kökenleri vardır aynı zamanda kültür tarafından da geliştirilir. Tüm insanlar bu değerlere yönelme eğilimindedir. Bazılarında bu çok güçlü bir biçimde görülürken bazılarında ise daha zayıf olarak görülür. Psikolojik açıdan sağlıklı insanlar, kendilerine özgür bir ortam ve seçme hakkı verildiğinde yanlış, kötü, çirkin olanı değil doğru, iyi, güzel, bütünleşmiş, neşe verici, canlı ve özgün olanı seçme eğiliminde olurlar. Kendileri ve başkaları için en iyi olanı seçerler. Onların seçimleri ve doruk deneyimlerde algılanan değerler aynı olmakla birlikte varlık değerlerini oluştururlar (Maslow 2011'den aktaran Kaba, 2018, s.60).

Maslow, değerlerden yoksunluğun; anomi, ahlaksızlık, köksüzlük, boşluk, umutsuzluk ve inanılacak, uğruna adanılacak şeylerin eksikliği gibi durumların ortaya çıkmasına neden olduğu görüşünü savunur. Maslow'a göre inanmaya ve inançlı olmaya teşvik eden değil, sadece doğru olmalarından dolayı inanılacak ve uğruna insanın kendisini adayabileceği, geçerli kılınabilen ve uygulanabilir bir insanî değerler sistemine ihtiyaç duyulmaktadır (Maslow, 1996'dan aktaran Kaba, 2018, s. 61).

Naagarazan (2006, s.3) “Tüm değerler aynı ağırlık veya önceliğe sahip değildir. Bazıları diğerlerinden daha önemlidir ve diğerleri ele alınmadan önce yerine getirilmelidir. Abraham Maslow bunu insani ihtiyaçlar hiyerarşisi ile gösterdi." şeklindeki ifadeleriyle Maslow'un İhtiyaçlar Hiyerarşisi'nin değerlerle bağlantılı olduğunu ortaya koymuştur. Maslow'a göre piramidin alt basamağındaki bir ihtiyaç karşılanmadan diğer bir ihtiyaca geçilemez. Maslow'un ilk ihtiyaçlar piramidi 5 basamaklıdır. Piramidin en alt basamağındaki bir ihtiyaç karşılanmadan diğer bir basamağa geçilemez. İlk ihtiyaçlar piramidinde an alt basamakta biyolojik ve fiziksel ihtiyaçlar(temel yaşam ihtiyaçları:hava, yeme-içme, barınma, ısınma, cinsellik vb.), ikinci basamakta güvenlik ihtiyacı (İş, servet, sağlık, korunma, güvenlik, düzen, kanun, sınır, istikrar, vb.), üçüncü basamakta ait olma ve sevgi ihtiyacı(Aile, sevgi, dostluk, çalışma/iş grubu, vb.), dördüncü basamakta Özdeğer ve Özsaygı İhtiyacı (Başarı, statü, sorumluluk, itibar/ün, saygı vb.), en üst basamakta ise Kendini Gerçekleştirme ihtiyacı (Ahlak, kabul etme, doğal olmak, yaratıcılık vb.) yer alır. . Maslow bu ihtiyaçlara 
Bilme ve Anlama İhtiyacı (Bilme, anlama, öz-farkındalık vb.) ve estetik ihtiyaçlarını eklemiş ( Güzellik, denge, form, vb.) en üst basamağa ise kendini gerçekleştirme basamağından sonra aşkın olmak/öz-aşkınlık'ı koymuştur. Ancak aşkın olmak/öz-aşkınlık pek kabul görmemiştir. Araştırmaya temel alınan Maslow'un 7 basamaklı piramidi Şekil 1'de verilmiştir.

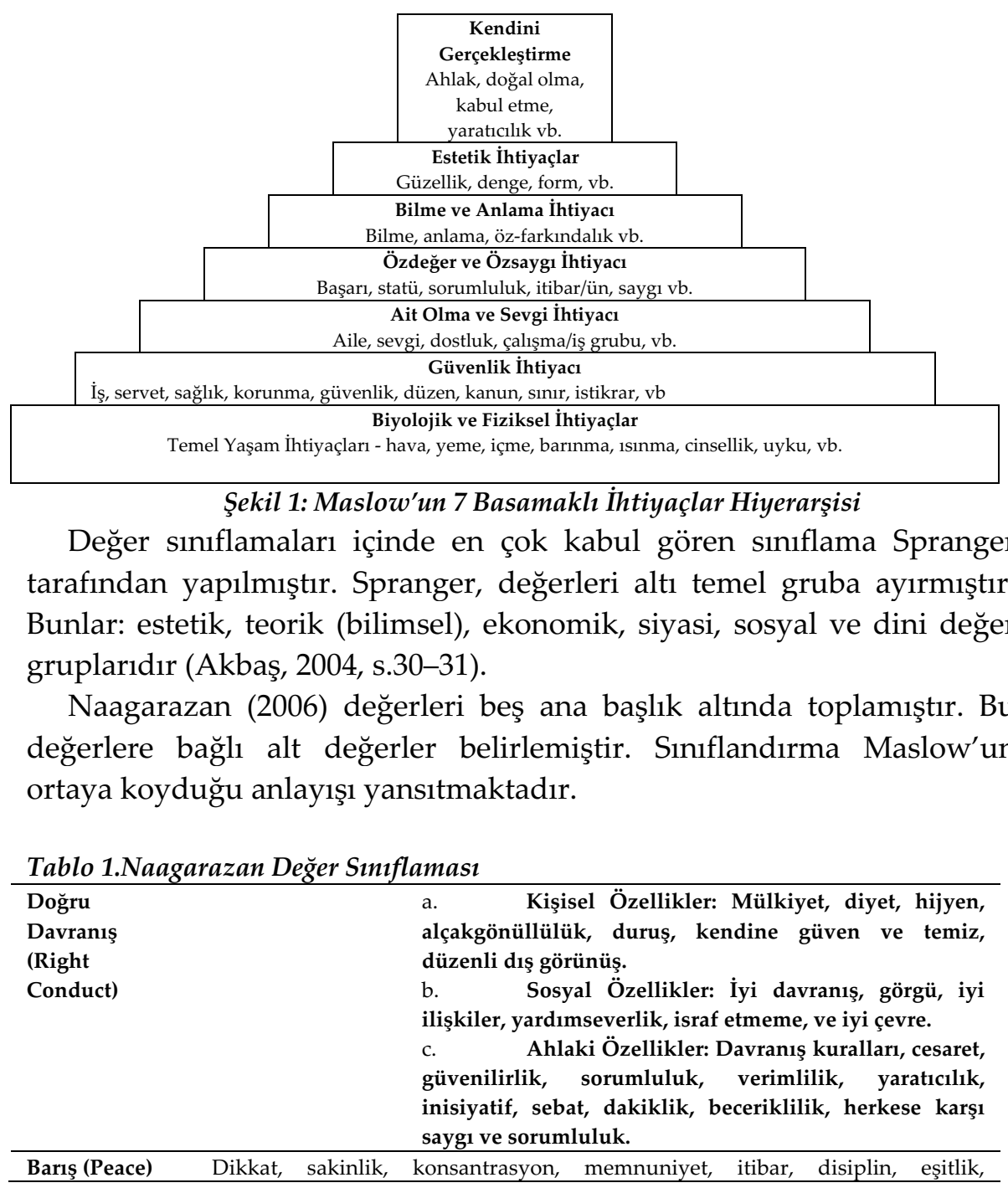


ağırbaşlılık, sadakat, odaklanma, şükran, mutluluk, uyum, alçakgönülllülük, iç sessizlik, iyimserlik, sabır, yansıma, memnuniyet, kendini kabul, kendine güven, öz kontrol, öz disiplin, öz saygı, özgüven, duygu kontörlü, tolerans ve anlayış.

\begin{tabular}{ll}
\hline $\begin{array}{l}\text { Doğruluk } \\
\text { (Truth) }\end{array}$ & $\begin{array}{l}\text { Doğruluk, merak, ayırt etme, tarafsızlık, korkusuzluk, dürüstlük, bütünlük } \\
\text { (düşünce, söz ve eylem birliği), sezgi, adalet, iyimserlik, saflık, bilgi arayışı, } \\
\text { akıl, öz-analiz, samimiyet, sorgulama ruhu, sentez, güven, doğru sözlülük ve } \\
\text { kararlılık. }\end{array}$ \\
\hline Sevgi (Love) & $\begin{array}{l}\text { Kabul, sevgi, özen, şefkat, dikkat, özveri, bağlllık, empati, hoşgörü, affetme, } \\
\text { dostluk, cömertlik, nezaket, insanlık, sadakat, sabır, vatanseverlik, saygı, } \\
\text { fedakarlık, özveri, hizmet, paylaşım, sempati, düşünceli olma, güven. }\end{array}$ \\
\hline
\end{tabular}

Şiddetsizlik

(Non-Violence) a. Psikolojik: Yardımseverlik, şefkat, başkaları için kaygılanma, dikkate alma, hoşgörü, affetme, görgü, mutluluk, sadakat, ahlak ve evrensel sevgi.

b. Sosyal: Diğer kültür ve diğer dinlerin takdir edilmesi, kardeşlik, çevre bakımı, vatandaşlık, eşitlik, zararsızlık, ulusal farkındalık, sebat, mülkiyete saygı ve sosyal adalet.

Schwartz (1994)'ın değer sınıflaması şöyledir: “Güç, başarı, hazcılık, uyarılım, öz yönelim, evrenselcilik, iyilikseverlik, geleneksellik, uyma, güvenlik". Akbaş doktora tezinde eğitim sayesinde benimsetilebilecek değerleri; "saygılı olmak, demokratik olmak, erdemli olmak, uyumlu olmak, işbirliği yapmak, kibar olmak, hoşgörülü olmak" olarak belirlemiştir (Akbaş, 2004, s.92)

Birkök, bir ilkenin değer olabilmesi için muhatapların tümü tarafından anlamlı, önemli ve içselleştirilmiş olması gerektiğini ifade etmiştir. Evrensel temel değerleri beş gruba ayırmıştır. Ele alınan değerler sosyolojik anlamdaki olgusal değerlerdir. Bunlar; özgürlük, eşitlik, sanat, adalet ve bilimdir. Birkök'e göre diğer değerler bu beş değerden türemiştir. Birkök'ün değerler sinıflaması da Maslow'un ihtiyaçlar piramidi ile paralellik arz etmektedir. Birkök'e göre bilimsel çalışmaların amacı gözlem ve deney yoluyla toplumsal gerçeklikteki mevcut mekanizmaları bulmak ve ifade etmektir. Böyle bir saptamanın da ancak tüm insan topluluklarının ve etiğin de dayandığ1 evrensel değerlerin belirlenmesiyle mümkün olacağını belirtir (Birkök, 2019, s.493).

Değerler eğitimi bireyin kendi kendini tanımasını, kendi ile uyum içinde olmasını, düşünüş ve eylemlerinde tutarlı olmasını sağlayan özelliklerin kazandırılması için bilinçli ve planlı bir öğrenme 
ortamlarının oluşturulmasıdır. Değerler eğitimi, öğrencilerin iç motivasyonlarını geliştirmelerine, neyin doğru olduğuna yönelik yorum yapmalarına ve bunu davranışa dönüştürmelerine olanak sağlar (Akbaş, 2008).

Değer kazanma süreci çocuklukta başlar (Silah, 2000). Özellikle küçük yaşlarda kişilik şekillenmesinin temelleri oluştuğundan, erken çocukluk yıllarının önemi daha da önem kazanmaktadır (Doğanay, 2009). Bunun sonucunda ailede değerler eğitimi ön plana çıkmaktadır. Ebeveynler çocuğa değerleri kazandırırken bilinçli bir şekilde davranmalıdır.

Günümüzde hırsızlık, cinayet, tecavüz gibi suçların yaygınlaşması değerler eğitiminin gerekliliğini ön plana çıkarmaktadır. Bu suçların önlenmesi amacıyla değerler eğitimi çalışmaları yapılmaktadır.

Çizgi filmlerde açık veya örtük bir biçimde değerler kazandırılmaya çalışılmaktadır. Çizgi filmler bu anlamda önemli bir yere sahiptir. Bu araştırmanın amacı 9-11 yaş çocuklarına yönelik TRT Çocuk kanalında yayınlanan "Pırıl" adlı çizgi filmin değerler eğitimindeki rolünün belirlenmesidir. $\mathrm{Bu}$ araştırma son ylllarda oldukça önem kazanan değerler eğitimine yönelik olduğu için hem güncel hem de gerekli bir araştırmadir.

\section{Problem Durumu}

Araştıranın problem cümlesi şu şekilde ifade edilmiştir: “ TRT Çocuk kanalında yayınlanan 9-11 yaş çocuklarına yönelik Pırıl çizgi filminde hangi değerler yer almaktadır?

\section{Alt Problemler}

- Pırıl çizgi filminde ağırlıklı olarak üzerinde durulan değerler hangileridir?

- Pırıl çizgi filminde daha az üzerinde durulan değerler hangileridir?

- Pırıl çizgi filminde hangi değerler üzerinde durulmamıştır?

\section{Yöntem}

\section{Araştırmanın Modeli}


Bu araştırmada nitel araştırma yöntemlerinden olan doküman incelemesi tekniği kullanılmıştır. Doküman incelemesi, araştırılması hedeflenen olgu veya olgular hakkında bilgi içeren yazılı materyallerin anazilini kapsar. Yazılı kaynakların yanı sıra, film, video ve fotoğraf gibi görsel malzemeler de nitel araştırmalarda kullanılabilir (Yıldırım ve Şimşek, 2018, s.189-190).

Araştırmada bu yöntemle 30 bölümden oluşan Pırıl çizgi filminin Youtube üzerinden en fazla izlenen 5 bölümlük senaryosuna ilişkin doküman incelenmiştir.

\section{Örneklem / Araştırma grubu}

Araştırmada TRT Çocuk kanalında yayınlanan 9-11 yaş grubu çocuklara yönelik "Pırıl" adlı çizgi filmin Youtube üzerinden en çok izlenen 5 bölümü örneklem olarak alınmıştır. Örneklem seçiminde benzeşik örneklem yöntemi kullanılmıştır. Homojen (benzeşik) örnekleme (homogeneous sampling). Maksimum çeşitlilik örneklemenin tam tersi olan homojen örneklemede amaç, küçük ve homojen bir örneklem ele alarak belli alt grupları derinlemesine çalışmaktır (Yıldırım ve Şimşek, 2018, s.120).

\section{Veri Toplama Araçları}

Araştırmaya başlamadan önce alanyazını incelenmiş, konu hakkında yayınlanmış makale, tez ve kitaplar okunarak bilgi sahibi olunmuştur. Ardından ilgili çizgi filmin Youtube izlenme oranları dikkate alınarak bu çizgi filmin en çok izlenen 5 bölümü içerik analizi yoluyla en az iki kez izlenerek taranmıştır. İçerik analizi "sözel, yazılı, elektronik veya diğer materyallerin içerdiği mesajı, anlam ve/veya dilbilgisi açısından nesnel ve sistematik olarak sınıflandırma, sayılara dönüştürme ve çıkarımda bulunma yoluyla sosyal gerçeği araştıran bilimsel bir yaklaşımdır" (Tavşancıl ve Aslan, 2001, s.22). Çizgi filmde yer alan değerler öncelikle taslak olarak yazılmış, daha sonra bilgisayar ortamına aktarılmıştır. Tespit edilen değerlere ait örnekler verilirken çalışmanın güvenirliğini arttırmak için değerlerin geçtiği çizgi filmin hangi bölümü olduğu, hangi dakika ve saniyede geçtiği verilmiştir. Değerlerin sınıflandırılması yapılmıştır. Bu sinıflandırılma yapılırken Maslow'un 7 Basamaklı İhtiyaçlar Hiyerarşisi ölçüt olarak kullanılmış ve ihtiyaç-değer arasındaki 
ilişki bu sınıflandırmaya yansıtılmıştır. Doktora danışmanı Mustafa Altun'un yönlendirmesiyle Tablo 7'de ihtiyaç-değer ilişkisini ortaya koyabilmek için Maslow'un 7 Basamaklı İhtiyaçlar Hiyerarşisi kullanılmıştır. Maslow'un İhtiyaçlar Hiyerarşisi ile Birkök'ün (2019) beş temel evrensel değeri ilişkilendirilmiştir. Birkök'ün evrensel değerleri Mustafa Altun tarafından olgusal değerler, bunun dışında kalanlar ise duygusal değerler olarak sinıflandırılmıştır. Duygusal değerlerin çoğunluğu MEB'in Değerler Eğitimi Genelgesi'nde (MEB, 2010) yer alan değerlerle örtüşmektedir. Edepli olma, sözünde durma, eğitimli olma, sabır, pişmanlık, kanaatkârlık, kararlılık, cömertlik, azimli olma, inanç, teselli etme, sadakat, öğüt verme, ait olma, tedbir, diğergamlık Birkök ve MEB'in listesinin dışında kalan değerlerdir.

Maslow'un ihtiyaçlarının üst ve alt değerlerle ilişkili olduğu sonucuna varılmış, bu ilişki tabloda gösterilmiştir.

Tablo 2. İhtiyaç-Değer İlişkisini Gösteren Örnek Değer Sınıflaması

\begin{tabular}{|l|l|}
\hline Değerler & \\
1. Fizyolojik ihtiyaçlar & \\
\hline 1.1 Temiz Olma & \\
\hline 2. Güvenlik ihtiyaci & \\
\hline 2.1 Tedbir & \\
\hline Duygusal değerler & \\
\hline 3. Sevgi ve ait olma ihtiyaci & \\
\hline 3.1 Sevgi & \\
\hline 3.1.1 Diğergamlık & \\
\hline 3.1.2 Dostluk & \\
\hline 3.1.3 Duygudaşlık & \\
\hline 3.1.4 Fedakârlık & \\
\hline 3.1.5 Güven & \\
\hline 3.1.6 Hoşgörü & \\
\hline 3.1.7 Merhamet & \\
\hline 3.1.8 Misafirperverlik & \\
\hline 3.1.9 Nezaket & \\
\hline 3.1.10 Umutlu Olma & \\
\hline 3.1.11 Vefakârlık & \\
\hline 3.2 Ait Olma & \\
\hline 3.2.1 Dayanışma & \\
\hline 3.2.2 Duyarlılık & \\
\hline 3.2.3 Ögüt Verme & \\
\hline 3.2.4 Paylaşma & \\
\hline 3.2.5 Sadakat & \\
\hline 3.2.6 Sorumluluk & \\
\hline 3.2.7 Teselli Etme & \\
\hline
\end{tabular}




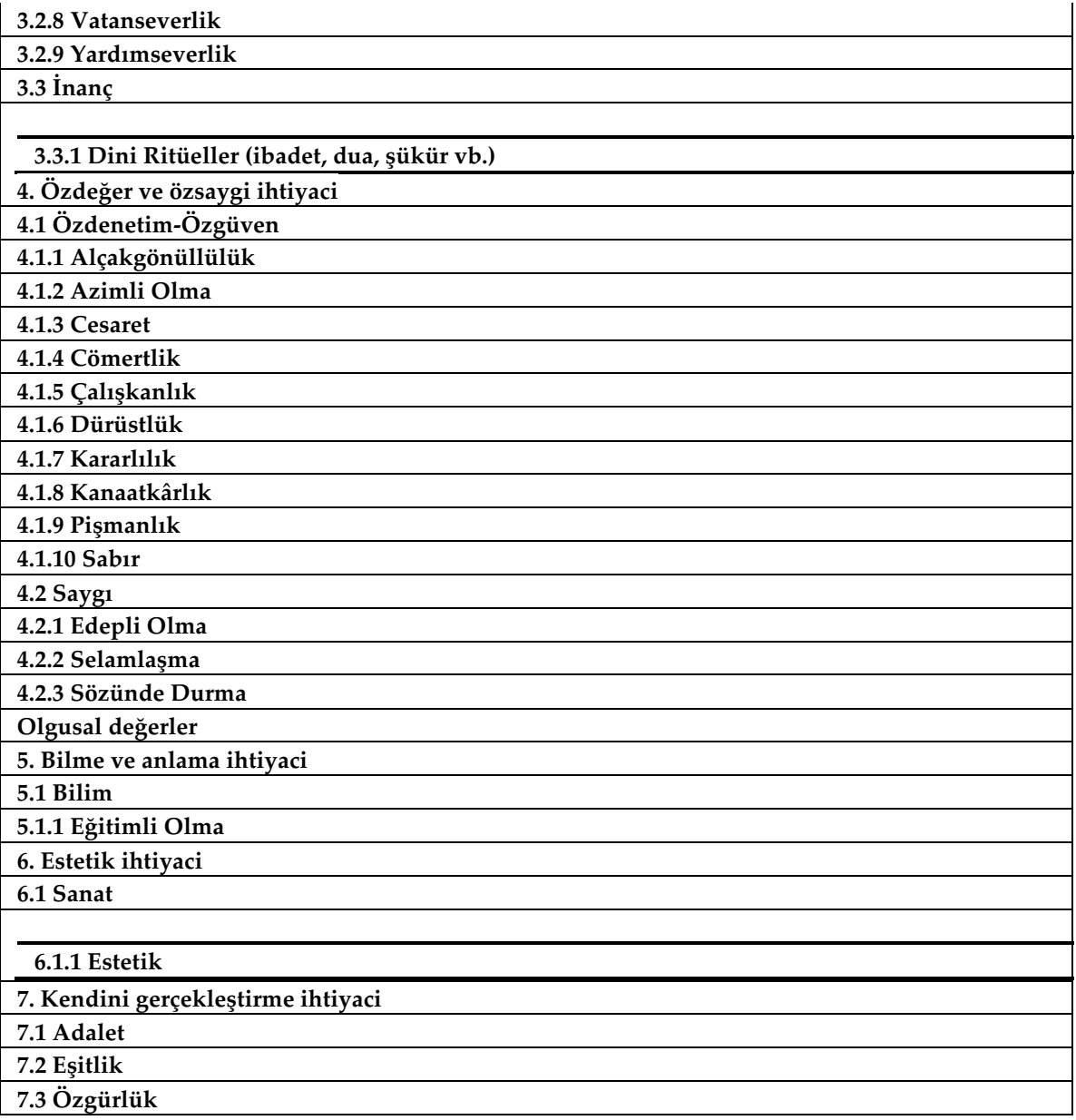

Tabloda ihtiyaç-değer ilişkisini ortaya koyabilmek için Maslow'un 7 Basamaklı İhtiyaçlar Hiyerarşisi kullanılmıştır. Bu sınıflandırmadan önce fizyolojik ve güvenlik ihtiyacı ele alınmıştır. Ardından duygusal değerler başlığı altına ihtiyaç piramidine göre öncelikle sevgi ve ait olma ihtiyac1, özdeğer-özsayg ihtiyacı yerleştirilmiştir. Olgusal değerler başlığı altında ise ihtiyaç piramidine göre bilme ve anlama ihtiyacı, estetik ihtiyacı ve kendini gerçekleştirme ihtiyacı yerleştirilmiştir. Birkök de yapmış olduğu değer sınıflamasında 5 temel evrensel değerden söz etmektedir. $\mathrm{Bu}$ yönüyle Maslow'un piramidinde yer alan ihtiyaçlara paralel olarak evrensel anlamda örtüşme sağlayan değerler tabloda alt başlıklarda 
gösterilmiştir. Bu değerler ihtiyaçlarla ilişkilendirilirken Birkök dışında, Schwartz, Spranger ve Naagarazan değer siniflamalarından yararlanılmıştır. Maslow'un piramidine göre kendini gerçekleştirme basamağı altında özgürlük, eşitlik ve adalet değerleri işlenmiştir. Schwartz da yapmış olduğu sınıflandırmada evrenselcilik başlığı altında adalet ve eşitlik değerlerine yer vermiştir (Akay,2018, s.102-103).

\section{Verilerin Analizi}

Araştırma verilerinin analizinde kategorisel içerik analizi yöntemi kullanılmıştır. Bu yöntemde 5 bölümün tamamı içerik analiz türlerinden kategorisel içerik analizi yöntemi ile incelenmiştir. Bu analizde temel amaç, toplanan verileri açıklayabilecek kavramlara ve ilişkilere ulaşmaktır (Yıldırım ve Şimşek, 2013, s.259).

Çalışmada değerler ayrı ayrı başlıklar halinde verilmiş ve çizgi filmin bölümlerinden örneklendirilmiştir. Soru işareti oluşturan durumlar alan uzmanıyla görüşülerek çözüme kavuşturulmuştur. İnceleme sırasında doğrudan ve dolaylı bir şekilde verilmiş olan değerler karakterlerin davranışlarından, gelişen olaylardan hareketle belirlenmiştir. Uzmanların ve araştırmacının tam mutabakatları sonrasında çalışma son şeklini almıştır.

\section{Bulgular}

Yapımcılığını Ali Sacihan'ın üstlendiği Pırıl çizgi filminin yönetmenliğini ve senaristliğini Neslihan Bayram Sacihan yapmaktadır. Çizgi film halen TRT Çocuk ekranlarında yeni bölümleriyle ekrana gelmektedir. Her bölüm ortalama 15.30 dakikadır. Çizgi filmin konusu şu şekildedir:

Pırıl ve arkadaşları 3. sınıfa gitmektedir. Çizgi filmde onların yaşadığı maceralar anlatılmaktadır. Çizgi filmin amacı çocuklara matematiği sevdirmek, eğlenceli bir şekilde öğretmektir.

Tablo 3. Pırıl Çizgi Filminde Geçen Değerler

\begin{tabular}{l|l|l}
\hline GEÇEN DEĞERLER & $\begin{array}{l}\text { DEĞERLERIN GEÇME } \\
\text { SIKLIĞI }\end{array}$ & GEÇTiĞİ BÖLÜMLER \\
\hline Sorumluluk & 12 & $19,22,14,21$ \\
\hline Ögüt verme & 2 & 14,19 \\
\hline
\end{tabular}




\begin{tabular}{l|l|l}
\hline Yardımseverlik & 2 & 19,21 \\
\hline Estetik & 14 & $14,16,19,21,22$ \\
\hline Dostluk & 1 & 19 \\
\hline Nezaket & 16 & $14,16,21,19,22$ \\
\hline Bilme ve anlama isteği & 2 & 19,22 \\
\hline Güven & 1 & 22 \\
\hline Özgüven & 3 & 22 \\
\hline Cömertlik & 1 & 22 \\
\hline Teselli etme & 5 & $22,14,16$ \\
\hline Hoşgörü & 2 & 21 \\
\hline Dürüstlük & 1 & 16 \\
\hline Sevgi & 3 & 16 \\
\hline Pişmanlık & 3 & 16 \\
\hline Selamlama & 1 & 16
\end{tabular}

Çizgi filmin incelenen 5 bölümünde toplam 69 değer tespit edilmiştir. $\mathrm{Bu}$ değerler sorumluluk, ögüt verme, yardımseverlik, estetik, dostluk, nezaket, bilme ve anlama isteği, güven, özgüven, cömertlik, teselli etme, hoşgörü, dürüstlük, sevgi ve pişmanlık olmak üzere 15 değere yer verilmiştir. Bunlar içerisinde en fazla yer alan değer "nezaket"tir. "nezaket" değeri incelediğimiz 5 bölümün tamamında toplam 17 kez geçmektedir. İkinci olarak en çok rastladığımız "estetik"tir. "Estetik" 5 bölümün tamamında toplam $14 \mathrm{kez}$ geçmektedir. Üçüncü olarak "sorumluluk" en çok geçen değerdir. Bu değer 5 bölümün 4'ünde toplam $12 \mathrm{kez}$ geçmektedir. Bunlar dışında teselli etme değeri $5 \mathrm{kez}$, özgüven, sevgi, pişmanlık değerleri 3 kez; ögüt verme, yardımseverlik, bilme ve anlama isteği, hoşgörü değerleri $2 \mathrm{kez}$; dostluk, güven, cömertlik ve dürüstlük değerleri ise 1 kez geçmektedir.

En fazla değere rastladığımız bölüm 19. bölümdür. "Bana Saati Söyle" adlı bölümde 22 değer tespit edilmiştir. Bölümde en fazla geçen değer "sorumluluk"tur. Bu bölümde buluşmalara zamanında gelmenin önemi üzerinde durulmuştur. Buluşmalara zamanında gelmek kişinin ne kadar sorumlu olduğunu gösterir. Bölümde nezaket ve estetik değerleri $4 \mathrm{kez}$ geçmektedir. $\mathrm{Bu}$ değerler çocukların eğitimi açısından oldukça önemlidir. Bu değerler dışında bilme ve anlama isteği, öğüt verme, yardımseverlik ve dostluk değerleri 1 kez geçmektedir.

Çizgi filmin "Kesirli Dondurmacı" adlı 22. bölümünde 14 değer tespit edilmiştir. En fazla geçen değer "nezaket"tir. "nezaket" değeri 4 kez geçmektedir. İkinci olarak “özgüven” 3 kez geçmektedir. Nazlı dengede 
durma konusunda kendine oldukça güvenmektedir. Bunlar dışında bilme ve anlama isteği, güven, cömertlik, teselli etme ve sorumluluk değerleri 1 kez geçmektedir.

"Geometrik Robotlar" adlı 21. bölümde toplam 9 değer tespit edilmiştir. En fazla geçen değer "nezaket"tir. Estetik ve hoşgörü değerleri 2 kez, yardımseverlik değeri ise 1 kez geçmektedir.

"Sayıların Kayboluşu" adlı 16. bölümde toplam 12 değer tespit edilmiştir. Sevgi, teselli etme ve pişmanlık değerleri 3 kez geçmektedir. Bölümde Efe önce sayıların yok olmasını dilemekte ancak sayılar yok olunca çıkan karışıklıktan dolayı bu isteğinden pişmanlık duymaktadır. Bu nedenle "pişmanlık" değerine sıkça yer verilmiştir. Ayrıca annesi ve Efe'nin birbirlerine olan sevgilerine yer verilmiştir. Bu sevgiyi sözle ve hareketleriyle göstermişlerdir. Diğer bölümlerde olduğu gibi "nezaket" değeri bu bölümde de önem taşımaktadır. "nezaket" değeri bölümde 2 kez geçer. Bölümde geçen bir diğer değer ise "dürüstlük"tür. "dürüstlük" değeri de $1 \mathrm{kez}$ tespit edilmiştir.

"Açı Sandalyesi" adlı 14. bölümde toplam 12 değer geçmektedir. En fazla geçen değer "estetik" değeridir. İkinci olarak "nezaket" değeri en fazla geçen değerdir. Bunlar dışında öğüt verme, sorumluluk ve teselli etme değerleri $1 \mathrm{kez}$ geçmektedir.

"Pırıl" çizgi filminden her bir değer bağlamında doğrudan alıntılar (bölüm numarası ve yapılan alıntının dakikası belirtilerek) sırasıyla şu şekildedir:

\section{Nezaket}

Nezaket başkalarına karşı saygılı davranmak, nazik ve ince olmaktır. Zerafeti gösterme sanatı olan nezaket tüm kültürler için önemli bir unsurdur. Nezaket, görgülü olmanın bir parçasıdır ve bireyler zamanla belirli bir görgü kazanırlar. Bireylerin başkalarına gösterdiği nezaket aynı zamanda kendisine verdiği değerle ilişkilidir. "Teşekkür ederim", "İyi günler" gibi nezaket ifadelerini kullanamayan, başkalarını rahatsız ettiğinin farkında olduğu halde rahatsız edici davranışını sürdüren bireyler nezaketten yoksun olan bireylerdir (Misırlı, 2011: 7- 8). Nazik insanlar hiçbir zaman başkalarını rahatsız etmez, kırmaz, karşılarındaki kişilere iyi davranmaya, kibar olmaya çalışırlar. "nezaket" değeri "Pırıl" 
çizgi filminde de "teşekkür etme, iyi dileklerde bulunma, rica etme, gelen kişiye hoş geldin deme, özür dileme şekillerinde karşımıza çıkmaktadır.

\section{Örnek Cümleler}

Nazlı'yı annesi eve geldiğinde "hoş geldin (19. bölüm, 9.59) diyerek karşılar.

“Hoş geldin.”(19.bölüm,9.59)

Pırıl'a annesi saatleri öğrendiği için bir saat hediye eder. Pırıl saati beğenerek annesine teşekkür eder:

“Teşekkür ederim."(19. Bölüm, 10.33)

Annesi Pırıl'a yeni aldığı saat için iyi dileklerde bulunur:

“Güle güle kullan canım.”(19. Bölüm, 10.37)

Annesi Pırıl'a ödevleri için iyi dileklerde bulunur:

"Kolay gelsin."(19. Bölüm, 10.00)

Annesi Uzay'dan ablasından kendisini dondurma yemeye götürmesi için rica etmesini söyler:

"Ablandan seni götürmesini rica edebilirsin mesela."(22. Bölüm, 5.25)

Uzay ve Mert Pırıl'ın yeni aldığ sonra Mert özür diler:

“Özür dileriz Pırıl Abla. "(14. Bölüm, 6.18)

Mert Pırıl'ın annesinin yemeklerini beğenir. Pırıl'ın annesi de Mert'e “afiyet olsun canım(21. Bölüm, 3.35) der:

\section{Estetik}

Estetik, TDK Güncel Türkçe Sözlük'te "güzellik duygusu ile ilgili olan" olarak tanımlanmıştır. Estetik duyusal alanın bütün genişliğini değil, özellikle güzel olan kısmını inceler (Ergün, 2010). Kendisine bakanda haz ile beğeni duyumları uyandıran nesnelerin en belirleyici niteliğini veya yetisini anlatan estetiğin temel kavramı; gönül okşamak, iç gıcıklamak, büyülemek, yaşama sevinci uyandırmak türünden hep olumlu duygulanımlar doğuran şeylerin veya sanat yapıtlarının en belirleyici nitelikleridir (Frozel, 2004'ten aktaran Gökay ve Demir, 2006). Çizgi filmde "estetik" değeri güzelliği, beğenileri dile getirmede kullanılmıştır. 


\section{Örnek Cümleler}

Cesur Nazlı'ya yardım etme fikrini çok beğenir ve arkadaşlığın önemine dikkat çeker:

“Harika!(19. Bölüm, 4.58)

Nazlı yelkovan kuşundan bahsedilmesinden çok hoșlanır:

“Ay çok tatlı!"(19. Bölüm, 7.23)

Nazlı kesirli dondurmacıyı beğendiğini ifade eder:

"Gerçekten çok güzeldi." (22.bölüm, 2.29)

Çocuklar Deha'nın icadına beğenilerini dile getirirler:

"Ben çok anlamam ama süper olmuş.(14. Bölüm, 8.37)

"Gerçekten çok güzel bir buluş olmuş." (14. Bölüm, )

“Şahane bir şeye benziyor."(14. Bölüm, 12.35)

\section{Sorumluluk}

Civelek (2006), sorumluluğu "Kurallara uyma, kavrama gücünü kulllanma, başkalarına ve onların mülklerine saygı ve özen gösterme" olarak tanımlamıştır. Sorumluluklarını yerine getirmenin bilincinde olan bir birey, daha iyiyi yapmak için daha duyarlı olacaktır. Bu sayede gelecek nesillere daha yaşanabilir bir dünya bırakılabilir. Sorumluluk değer eğitiminin amacı da, bireylerin sorumluluklarının farkına varmasını sağlamaktır (Aktepe, 2015, s.1512). "Pırıl" çizgi filminde "sorumluluk" değeri kişinin yapması gerekenlerin farkında olması ve bunu yerine getirmesi, randevularına vaktinde gitmesi şeklinde karşımıza çıkar.

\section{Örnek Cümleler}

Pırıl ve arkadaşı buluşma saatine bir dakika kala gelip diğer arkadaşlarını beklerler. Nazlı hariç herkes buluşmaya vaktinde gelir. Dolayısıyla Nazlı hariç diğer arkadaşlar sorumluluk sahibidir. Bu durum şu cümlelerle aktarılmıştır:

"Saat 8.29 bir dakika kaldı. (19. Bölüm, 1.54)

Tam zamanında.(19. Bölüm, 2.18)

"Yine geç kaldı." (19. Bölüm, 2.21)

"Geç kaldın." (19. Bölüm, 2.45)

“Yine geç kaldın Nazlı.”(19. Bölüm, 6.01) 
“Bundan sonra hiçbir yere geç kalmayacaksın."”(19. Bölüm, 6.04)

“Artık geç kalmak yok." (19. Bölüm, 9.44)

Öğrencinin en önemli sorumluluklarından bir tanesi ödev yapmaktır. Pırıl da annesinin uyarmasına gerek kalmadan ödevini yapmaya gider. Bu durum onun sorumluluk sahibi bir birey olduğunu gösterir:

“En iyisi ben hemen odama çıkıp ödevimi yapayım."(19. Bölüm, 10.38)

Pırıl annesinin sözünden çıkmaz. Bu da onun sorumluluk sahibi olduğunu gösterir:

“Olmaz annem ne söylediyse o." (22. Bölüm, 7.13)

Sorumluluğunu bilen çocuklar annesinden izinsiz hiçbir yere gitmez. Deha da arkadaşlarından okuldan sonra buluşunu görmeye annelerinden izin alarak gelmelerini ister:

“Annenizden izin alıp gelin.”(14. Bölüm, 4.42)

\section{Teselli Etme}

Teselli etme, TDK Güncel Türkçe Sözlük'te "avutmak, avundurmak" olarak tanımlanmıştır. Üzgün, acı çeken bir kişiyi gördüğünde onun yanına giderek ona yardımcı olmak, o kişiyi sözleriyle avutmak duyarlı, sorumluluğunu bilen bir kişinin yapması gereken bir davranıştır. Birbirini anlayan, birbirine değer veren insanlar iyi günlerinde yakınlarının yanında oldukları gibi kötü günlerinde de onları destekler, gerektiğinde teselli ederler. "Pırıl" çizgi filminde de bu değerin geçtiği bazı bölümler ve dakikaları aşağıda belirtilmiştir:

\section{Örnek Cümleler}

Cesur Nazlı yarışmayı kaybedince duruma bir de iyi tarafından bakmasını söyler ve dondurma yemeye gideceklerini söyleyerek onu teselli eder:

"Nazlıcım üzülme, sayemde sen de dondurma yiyeceksin."(22. Bölüm, 4.05)

“Sakin ol!”(14. Bölüm, 6.54)

Deha yangından dolayı korkan Nazlı'yı teselli eder:

“Korkma Nazlı burda değil." (16. Bölüm, 6.55)

Öğretmeni yangından korkan Nazlı'yı teselli eder: 
"Korkma canım şimdi itfaiyeci amcalar yangını söndürecekler." (16. Bölüm, 10.45)

\section{Sevgi}

Sevgi, bütün insani ilişkilerde herkesçe benimsenmesi gereken, insanların birbirlerine güven duymalarını, ilişkilerini geliştirmelerini ve böylece hayattan zevk almalarını sağlayan bir değerdir (Çintaş Yıldız, 2011, s.208). Sevgi değeri çocukların kişiliklerini oluşturmada önemli değerlerden bir tanesidir. Değerler okul öncesi dönemde kazanılmaya başladıkları için çizgi filmlerin de bu değerin kazanılmasında etkisi görülmektedir.

\section{Örnek Cümleler}

Çizgi filmde sevgi değeri anne-oğul sevgisi olarak karşımıza çıkmaktadır.

“Anneciğim seni çok seviyorum."(16. Bölüm, 14.21)

“Canım benim"(16. Bölüm,14.42)

“Canım annem"(16. Bölüm, 14.43)

\section{Örnek Cümleler}

Deha, Nazlı'ya saati öğrenmesi için yardımcı olmayı teklif eder:

“Ona analog saati öğrenmesinde yardımcı olmalıyız arkadaşlar." (19. Bölüm, 4.48)

Pırıl ödevlerini çoğu zaman arkadaşlarıyla birlikte yapmaktadır. Bu şekilde hep birlikte öğrenerek birbirlerine yardımcı olurlar: 3.57)

"Hem arkadaşlarım gelecek, birlikte ödev yapacağız."(21. Bölüm,

\section{Bilme ve Anlama İsteğ}

Bilim insanlığın gelişmesi için önemli değerlerden bir tanesidir. Bilimin temelinde ise merak duygusu yatar. "bilme ve anlama isteği" "Pırıl" çizgi filminde kişilerin öğrenmeye hevesli, meraklı olmaları şeklinde görülmektedir. 


\section{Örnek Cümleler}

Uzay ablasından kendisine saatleri öğretmesini ister:

"Bana da saatleri okumayı öğretsene abla."(19. Bölüm, 11.07)

Uzay kesirlerin ne olduğunu bilmez ve ne olduğunu sorar:

“O da ne demek?" (22. Bölüm, 7.22)

\section{Hoşgörü}

Hoşgörü, özellikle günümüz dünyasında en önemli erdemlerden biridir. İnsana özgü, insanı yücelten bir erdem. Hoşgörünün özünde anlayış gösterme, anlayışla karşılama yatar. Hoşgörü, olgunluğun belirtisidir. (Kavcar, 1995, s.5). Toplum ilişkilerinin sağlıklı bir şekilde yürüyebilmesi için insanların birbirlerine karşı hoşgörülü olmaları gerekir. Aile içerisinde bireylerin anlayışlı, hoşgörülü olmaları ailenin dağılmasını önler. Son yıllarda artan boşanmalar aile bireylerinin yeterince hoşgörü sahibi olmadığını göstermektedir. Bu nedenle hoşgörü değerinin önemi bir kez daha ortaya çıkmaktadır. Pırıl çizgi filminde hoşgörü değeri ablanın kardeşe karşı anlayışlı olması şeklinde tespit edilmiştir.

\section{Örnek Cümleler}

Annesi Pazar sabahı kardeşinin flüt sesiyle uyanan Pırıl'dan kardeşi flüt çalmayı öğrenene kadar anlayışlı olmasını ister:

"Kardeşin flüt çalmayı öğrenene kadar biraz anlayışlı olmalısın kızım." (21. Bölüm, 3.05)

Pırıl flüt öğrenen kardeşine karşı anlayışlı olacağını belirtir:

“Ablası olarak öğrenene kadar çok anlayışlı olacağım." (21. Bölüm, $5.04)$

\section{Dostluk}

Dost; sevgisinde samimi olan, iyi ve kötü günlerinde arkadaşının yanında olup onun daima iyiliğini isteyen, onu kötülüklerden korumaya çalışan kişidir. Dostluğun arkadaşlıktan farkı; dostluk bağının arkadaşlık bağından daha kuvvetli olması ve samimiyetin ön planda tutulmasıdır. 
Dostluk, sevgisinde samimi, içten olan insanların menfaatten uzak ilişkileridir (Altın, 2010) Pırıl ve arkadaşları çoğu zaman birlikte vakit geçirirler, birinin başı sıkıştığında diğerleri yardıma koşar. Çizgi filmde "dostluk" değerinin geçtiği bölüm ve cümle şu şekildedir:

\section{Örnek Cümle}

Cesur Nazlı'ya saatleri öğrenmede yardım etme fikrini çok beğenir ve arkadaşlığın önemine dikkat çeker:

“Arkadaşlığın gücü budur işte!”(19. Bölüm, 4.59)

\section{Güven}

Güven duygusu insanların birbirine daha iyi bağlanmasını sağlar. Arkadaşlık ve dostluğun temelinde güven duygusu yer alır. "Pırıl" çizgi filminde arkadaşlar arasında güven duygusu önemli yer tutar. Bu değere açlk bir şekilde yer verildiği gibi örtük bir şekilde arkadaşların çoğu zaman birlikte yer alarak birbirlerine destek olması da güven değerini gösterir.

\section{Örnek Cümle}

Deha denge yarışmasında Nazlı'yı destekler ve ona olan güvenini dile getirir:

“Bu iş Nazlı'nın işi."(2.48)

\section{Cömertlik}

Cömertlik TDK Güncel Sözlük'te "Cömert olma durumu, eli açıklık, ahilik, semahat, mürüvvet" olarak tanımlanır. Başkalarına maddi yardımda bulunmak, arkadaşlarına bir şeyler ismarlamak gibi davranışlar cömertliğin göstergesidir. İnsan gerektiğinde paylaşmayı bilmelidir.

\section{Örnek Cümle}


Pırıl yarışmayı Cesur kazanırsa dondurma 1smarlama sözü verir:

"Eğer olur da Cesur kazanırsa ikinizi dondurma yemeye götüreceğim arkadaşlar."(22. bölüm, 3.36)

\section{Dürüstlük}

Dürüstlük, TDK Güncel Sözlük'te "doğruluk" olarak tanımlanmıştır. Doğruluk ve güven değerleri birbirine bağlıdır. Yalan söyleyen kişiye kimse inanmaz, o kişiyle arkadaşlık kurmak istemez. Bu nedenle toplum olmanın temelinde yatan önemli değerlerden biri de "dürüstlük"'tür. Dürüstlük değeri "Pırıl” çizgi filminde açık bir şekilde kelimelerle ifade edilmekle birlikte çizgi filmin karakterlerinin yalan söylememeleri bu değerin örtük bir biçimde de yer aldığını göstermektedir.

\section{Örnek Cümle}

Efe annesine ders çalışma konusunda yalan söylemez:

“Gerçeği söylememi mi istiyorsun anne?"(16. Bölüm, 1.46)

\section{Tartışma ve Sonuç}

Çizgi filmler ebeveynler tarafından denetlenerek çocuğun yaşına uygun olanlar çocuklara izlettirilirse değerler eğitimi açısından çocuğa fayda sağlayabilir. Burada çocuğun televizyona maruz kaldığı süre oldukça önemlidir. Her ne kadar televizyonun çocuğun eğitimine katkı sağlayacağ düşünülse de çocuğun televizyona çok fazla zaman ayırmaması gerekir.

Çizgi filmler çocukların eğlenerek, sıkılmadan öğrenmesinde etkilidir. Özellikle incelenen "Pırıl" çizgi filmi matematik öğretimini farklı yollarla, çocukların ilgisini çekecek şekilde gerçekleştirmektedir. "Pırıl" karakteri davranışlarıyla ve sorumluluklarını bilmesiyle çocuklara örnek olabilecek nitelikte bir karakterdir. Bu özellikleri dolayısıyla "Pırıl" çizgi filmi incelenmeye değer bir niteliğe sahip bulunarak değerler eğitimine katkısı incelemeye tabi tutulmuştur.

Pırıl isimli çizgi filmi özellikle 9-11 yaş grubuna hitap etmekte, matematik öğretimine katkı sağlamaktadır. Çizgi filmde matematik 
eğlenceli olarak işlenmekte ve çocuklara sevdirilmeye çalışılmaktadır. Maslow'un 7 basamaklı ihtiyaçlar hiyerarşisi, Schwartz, Spranger ve Naagarazan, Birkök değer sinıflamalarından harmanlayarak değerlendirmeye alınan 47 değerden 15 tanesine çizgi filmde yer verildiği görülmektedir. Bu bağlamda değerlendirildiğinde oluşturulan tablodaki değerlerin yarıdan azına yer verilmiş olması çizgi film açısından bir eksikliktir. Temiz olma, tedbir, diğergamlık, duygudaşlık, fedakârlık, merhamet, misafirperverlik, umutlu olma, vefakakârlik, ait olma, dayanışma, duyarlılık, paylaşma, sadakat, vatanseverlik, inanç, alçakgönüllülük, azimli olma, cesaret, çalışkanlık, kararlılık, kanaatkârlık, edepli olma, saygı, sabır,eşitlik, özgürlük, adalet,sanat ve sözünde durma değerlerine hiç yer verilmemiştir.

Araştırma sonucunda incelenen 5 bölümde toplam 69 değer tespit edilmiştir. Bu açıdan değerlendirildiğinde Pırıl adlı çizgi filmin değeler bakımından zengin olduğu söylenebilir. Bu değerler arasında "estetik ve nezaket" değerleri en sik rastlanan değerlerdir. Çok sık geçen bu değerlerden sonra "sorumluluk ve teselli etme" değerleri gelmektedir. Estetik değeri çizgi filmin incelenen bölümlerinde 14 defa, nezaket değeri 16 defa, sorumluluk değeri 12 defa, teselli etme değeri ise 5 defa tespit edilmiştir.

Araştırmaya konu edinilen Pırıl çizgi filmi barındırdı̆̆g değerler dolayısıyla değerler eğitimine katkı sağlayabilecek niteliktedir. Bu nedenle bu çizgi filmden değerler eğitiminde yararlanılabilir. Ayrıca araştırmaya konu edinilmeyen çizgi filmlerdeki değerlerin de tespit edilip bu çizgi filmlerden de değerler eğitiminde yararlanılması önemlidir.

İncelenen çizgi filmde nezaket, estetik gibi değerler ağırlıklı olarak geçmektedir. Bu açıdan değerlendirildiğinde çizgi filmde sadece belli değerlere değil, az tespit edilen ya da hiç tespit edilmeyen değerlere de yer verilmelidir.

Aileler çocukların izledikleri çizgi filmleri denetlemeli, çocuklarını Pırıl gibi değerler bakımından zengin çizgi filmleri izlemeye yönlendirmelidir.

İzlenen çizgi film her ne kadar değerler açısından zengin olsa da çocukların çizgi filmi izleme süreleri sınırlı tutulmalıdır. 
Değerler eğitiminde çizgi filmlerden daha aktif şekilde yararlanmak için daha fazla çalışmalar yapılmalı, öğretmenler ve öğrenciler bu çizgi filmleri izlemeleri veya izlettirmeleri konusunda teşvik edilmelidir.

Okullarda kullanılan kaynaklarda da bu çizgi filmlerin isimleri belirtilerek değerler eğitiminde yararlanılmalarına olanak sağlanmalıdır. 


\title{
EXTENDED ABSTRACT
}

\section{Evaluation of "Pir1l" Cartoon in Terms of Values Education}

\author{
* \\ Zehra Güden Altmış - Mustafa Altun \\ Sakarya University
}

With the development of technology, individuals have been interacting with technological tools since infancy. Today, devices such as televisions and mobile phones are in almost everyone's home. Therefore, these tools are effective on children. The fact that children are more passive in front of television makes the relationship between television and children more remarkable(Güneş, 2010, s.56). Considering the programs and cartoons prepared especially for children recently, it can be said that most of them aim to educate while entertaining. Cartoons are children's favorite viewing preferences. Cartoons are great fun and kids don't like to be bored. Cartoons also teach children a lot and expand their imagination. In addition, many cartoons are fantastic, which distracts children from reality (Garden, 2008). Although the idea that television takes precedence over families, schools and teachers has become more accepted recently, television should be used to enrich teaching in education (Okur ve Göçen, 2012, s.1991).

Today, the prevalence of crimes such as theft, murder and rape highlights the necessity of values education. Values education studies are carried out in order to prevent these crimes. In this research, Pirll cartoon, which is a domestic production on TRT Kids channel, was examined in terms of values education. This research is both an up-todate and necessary research since it is aimed at values education, which has gained importance in recent years. The cartoon named Pirll especially appeals to the 9-11 age group and contributes to the teaching of mathematics. In the cartoon, mathematics is processed as fun and it is tried to be liked by children. The document analysis technique, which is one of the qualitative research methods, was used in the research. In the research, the 5 most watched episodes of the cartoon called "Pirll" for 9- 
11 age group children, broadcast on TRT Çocuk channel, were taken as a sample. Homogeneous sampling method was used in sample selection. The 5 most watched episodes of the cartoon on Youtube were viewed at least twice through content analysis and scanned. A table of values was prepared based on the approach of Birkök's classification of values and Maslow's Hierarchy of Needs. All 5 sections were analyzed by categorical content analysis method, one of the content analysis types. In our research, the values are given under separate titles and exemplified from the parts of the cartoon. A

$t$ the end of the research, It is seen that 15 of the 47 values evaluated by blending Maslow's 7-level hierarchy of needs, Schwartz, Spranger and Naagarazan, Birkök value classifications are included in the cartoon. When evaluated in this context, it is a shortcoming in terms of cartoons that less than half of the values in the table created are included. Cleanliness, caution, altruism, sympathy, self-sacrifice, compassion, hospitality, hopefulness, loyalty, belonging, solidarity, sensitivity, sharing, loyalty, patriotism, faith, humility, tenacity, courage, diligence, determination, frugality, decency The values of respect, patience, equality, freedom, justice, art and keeping one's word are not included.

As a result of the research, a total of 69 values were determined in the 5 sections examined. From this point of view, it can be said that the cartoon named Pirll is rich in values. Among these values, "aesthetics and courtesy" values are the most common values. After these values, which are frequently mentioned, the values of "responsibility and consolation" come. The aesthetic value was determined 14 times, the courtesy value 16 times, the responsibility value 12 times, and the consolation value 5 times in the examined parts of the cartoon. The Prrl cartoon, which is the subject of the research, is capable of contributing to values education due to the values it contains. Therefore, this cartoon can be used in values education.

In addition, it is important to determine the values in the cartoons that are not the subject of the research and to benefit from these cartoons in values education. Values such as courtesy and aesthetics are predominantly mentioned in the cartoons examined. When evaluated from this point of view, not only certain values should be included in the cartoon, but also values that are less or not detected at all.Families 
should supervise the cartoons that children watch, and encourage their children to watch cartoons rich in values such as Pirll.Although the cartoons watched are rich in values, the children's time to watch cartoons should be limited.More studies should be done in order to benefit from cartoons more actively in values education, teachers and students should be encouraged to watch or have these cartoons watched.The names of these cartoons should be specified in the resources used in schools, and it should be possible for them to be used in values education.

\section{Kaynakça / References}

Akay, İ. (2019). Ahmet Yılmaz Boyunağa'nın çocuk romanlarının değerler eğitimi bağlamında incelenmesi. (Yayımlanmamış yüksek lisans tezi), Sakarya Üniversitesi, Sakarya.

Akbaş, O. (2004). Türk Milli Eğitim Sisteminin duyuşsal amaçlarının ilköğretim II. kademedeki gerçekleşme derecesinin değerlendirilmesi. (Yayınlanmamış doktora tezi). Gazi Üniversitesi, Ankara.

Akbaş, O. (2008). Değer eğitimi akımlarına genel bir bakış. Değerler Ĕ̆itimi Dergisi, 6(16), 9-27.

Aktepe, V. (2015). 5. sinıf öğrencilerinin sorumluluk değerinin geliştirilmesine yönelik bir performans görevi uygulaması. K. $\ddot{U}$. Kastamonu Ĕ̆itim Dergisi 23 (4), 1511-1534.

Altın, F.T. (2010). Mevlana'nın eserlerinde dostluk ve samimiyet değerlerinin işlenişi ve eğitim açısından tahlili. (Yayımlanmamış yüksek lisans tezi). Selçuk Üniversitesi, Konya.

Birkök, M. C. (2019). Değerler sinıflandırması. Journal of Human Sciences, 16(2), 493-498.

Büyükbaykal, G. (2012). Televizyonun çocuklar üzerindeki etkileri. İstanbul Üniversitesi İletişim Fakültesi Dergisi 28, 31-44. 07.06.2021 tarihinde https://dergipark.org.tr/en/pub/iuifd/issue/22861/244105 adresinden erişilmiştir

Can, A. (1995). Okulöncesi çocuklara yönelik televizyon programlar içinde çizgi filmlerin çocukların gelişimine etkisi. (Yayımlanmamış doktora tezi). Marmara Üniversitesi, İstanbul.

Can, A. (1996). Çocuk ve çizgi film. Konya: Öz Eğitim Yayınları.

Civelek, B. (2006). Çocuklara sorumluluk bilinci kazandırmak. Çoluk Çocuk Aylık Anne Baba Eğitimci Dergisi, 58, 20-22. 
Çakmak, H. (2018). Abraham Maslow'un "Kendini Gerçekleştirme" kavramının Aziz Nesefínin "İnsan-ı Kâmil" kavramıyla karşılaştırılması. (Yayımlanmamış yüksek lisans tezi). Eskişehir Osmangazi Üniversitesi, Eskişehir.

Çilenti, K. (1980). Çocuk ve kitle iletişim araçları, çocuk ve eğitim. Ankara: Türk Eğitim Derneği Yayınları.

Çintaş Y. D. (2011). İbrahim Zeki Burdurlu'nun eserlerinde sevgi değeri. Türkiyat Araştırmaları Dergisi, 203-230.

Doğanay, A. (2009). Değerler eğitimi. (Editör: Cemil Öztürk). Hayat Bilgisi ve Sosyal Bilgiler Öğretimi Yapılandırmacı Bir Yaklaşım. Ankara: Pegem A Yayıncilik.

Ergün, M. (2010). Felsefeye giriş(estetik). 07.06.2020 tarihinde http://mustafaergun.com.tr/wordpress/wpcontent/uploads/2015/11/s anatfelsefesi.pdf adresinden erișildi.

Garden J (2008). How does cartoon violence affect children. How does cartoon violence affect children. to genres and trends. 20.02.2021 tarihinde http://www.entertainmentscene360.com/index.php/ how-doescartoon-violence-affect-children-25755/ adresinden erişildi.

Gökay, M. ve Demir, A. (2006). Farklı eğitim seviyelerinde estetik beğeni. Selçuk Üniversitesi Sosyal Bilimler Enstitüsü Dergisi,16, 329-342.

Güler, Deniz A. (2013). Soyutun somutlaştırılması: Çizgi filmlerin kültürel işlevleri. I. Türkiye Çocuk ve Medya Kongresi Bildiriler Kitabı-1., haz. H. Yavuzer ve M. R. Şirin, İstanbul: Çocuk Vakfı Yayınları, s.207-216.

Güneş, V. (2010). Çizgi film karakterlerinin çocukların satın alma davranışlarında etkileri. (Yayımlanmamış yüksek lisans tezi), Sakarya Üniversitesi, Sakarya.

Kaba, F. (1992). Animasyonun eğitim amaçlı kullanımı. (Yayımlanmamış yüksek lisans tezi). Anadolu Üniversitesi, Eskişehir.

Kaba, B. (2018). Abraham Maslow ve din. (Yayımlanmamış yüksek lisans tezi). Eskişehir Osmangazi Üniversitesi, Eskişehir.

Kara, M ve Şıhlaroğlu Yıldırım, B. (2017). Nasreddin Hoca fikralarında kalıp sözler. International Journal of Languages' Education and Teaching, 5(1), 487-498.

Kavcar, C. (1995). Aç1lış konuşması. Okulda Hoşgörü ve Eğitim Toplantısı, 1-5, Ankara.

Kuşdil, ME, Kağıtçıbaşı, Ç. (2000). Türk öğretmenlerin değer yönelimleri ve Schwartz değer kuramı. Türk Psikoloji Dergisi, 15(45), 59-80. 
Maslow, A. H. (1943). A Theory of human motivation. Psychological Review, 50(4), 370-396.

MEB (2010). 2010/53 sayılı değerler eğitimi genelgesi, Millî Eğitim Bakanlığ1 Talim ve Terbiye Kurulu Başkanlığı, 20.02.2021 tarihinde http://mebk12.meb.gov.tr/meb_iys_dosyalar/10/05/743046/dosyalar/ 2013_02/24015229_deerlereitimiynergesi.pdf adresinden erişildi.

Misırlı, İ. (2011). Görgü, nezaket ve protokol: kurallar uygulamalar. (3. Bask1) İstanbul: Detay.

Naagarazan, R. S. (2006). A Textbook on professional ethics and human values. New Delhi: New Age International Publishers.

Okur, A. ve Göçen, G. (2012). Güzel konuşmada televizyonu kullanabilmek ve bir model. Sosyal Politika Çalışmaları, 7(29), 87-103.

Özeskici, D. (2014). Çizgi filmlerin görsel sanatlar dersi açısından önemi hakkında öğretmen ve öğrenci görüşleri. (Yayımlanmamış yüksek lisans tezi). Niğde Üniversitesi, Niğde.

Özkan, R. (2004), Televizyonun eğitimdeki yeri ve televizyon dizilerinde verilmek istenen mesaj. Millî Ĕ̆itim, 162, 45-56.

Öztürk, C. ve Karayağız, G. (2007). Okul öncesi dönemdeki çocukların televizyon izleme durumları ve bunu etkileyen durumların incelemesi. Milli Ĕ̆gitim Dergisi, 175,116-128.

Schmidt, M. A., ve Vandewater, E. A. (2008). Media and attention, cognition, and school achievement. The Future of Children, 18 (1),63-85.

Schwartz, S. H. (1994). Are there universal aspects in the structure and content of human values? Journal of Social Issues, 50 (4), 19-45. Erişim adresi: https://www.researchgate.net/publication/227762767_Are_There_Universal_Aspects_in_the_Structure_and_Contents_of_Hu man_Values

Silah, S. (2000). Sosyal psikoloji. Ankara: Gazi Kitabevi.

Tavşancıl, E. ve Aslan, E. (2001). Sözel, yazılı ve diğer materyaller için içerik analizi ve uygulama örnekleri. İstanbul: Epsilon Yayıncılık.

TDK Güncel Türkçe Sözlük. 02.06.2020 tarihinde www.tdk.gov.tr adresinden erişildi.

Wade, C ve Travis, C. (1993). Psychology. New York: Harper Collins publisher.

Yıldırım, A. ve Şimşek H. (2013). Sosyal bilimlerde nitel araştırma yöntemleri. Ankara: Nobel Yayın Dağıtım. 


\section{Kaynakça Bilgisi / Citation Information}

Güden-Altmış, Z. Ve Altun, M. (2021). "Pırıl" çizgi filminin değerler eğitimi açısından değerlendirilmesi. OPUS-Uluslararası Toplum Araştırmaları Dergisi, 17(38), 5382-5411. DOI: 10.26466/opus.752885. 